\title{
Dependability Characteristics - Indicators for Maintenance Performance Measurement of Manufacturing Technology
}

\author{
Adam Teringl ${ }^{1}$, Zdeněk Aleš², Václav Legát ${ }^{2}$ \\ ${ }^{1}$ NET4GAS, s.r.o., Na Hřebenech II 1718/8, CZ-140 21 Praha 4 - Nusle, Czech Republic, E-mail: adam.ter- \\ ingl@net4gas.cz \\ ${ }^{2}$ Faculty of Engineering, Czech University of Life Sciences Prague, Department for Quality and Dependability of Ma- \\ chines, Kamýcká 129, 16521 Prague 6-Suchdol, Czech Republic, E-mail: ales@tf.czu.cz, legat@tf.czu.cz
}

Authors define general dependability characteristics (reliability, maintainability, supportability and availability) and their measures. Further there is introduced method of data collection which shall be planned taking into account appropriate targets. Dependability data analysis needs clear understanding of an object, its operation, environment and physical attributes to be obtained required dependability measures which are described. These measures can be used as indicators for measuring maintenance impacts on reliability and maintainability. Data collection and its evaluation help to monitor the impact of maintenance on these indicators. Dependency between non-fulfillment of preventive maintenance and failure intensity including maintenance costs are also evaluated.

Keywords: Maintenance, Reliability, Availability, Preventive maintenance, Fulfillment of maintenance

\section{Acknowledgement}

Paper was created with the grant support - CZU IGA 2015 - 31190/1312/313117 - Operation quality and energy consumption of rotary cutter.

\section{References}

[1] SUGIER, J., ANDERS, G. J. (2013). Modelling and evaluation of deterioration process with maintenance activities. In: Eksploatacja i Niezawodnosc - Maintenance and Reliability; 15 (4): pp. 305-311. ISSN 1507-2711

[2] ZHANG, CH., WANG, S. (2013). Solid lubricated bearings performance degradation assessment: A fuzzy selforganizing map method. In: Eksploatacja i Niezawodnosc - Maintenance and Reliability; 15 (4): pp. $397-402$. ISSN 1507-2711

[3] KUMAR, J., KADYAN, M. S., MALIK, S. CH. (2012). Cost analysis a two-unit colt standby system subject to degradation, inspection and priority. In: Eksploatacja i Niezawodnosc - Maintenance and Reliability; 14 (4): pp. 278-283. ISSN 1507-2711

[4] ZHOU, Y., MA, L., MATHEW, J., SUN, Y., WOLFF, R. (2009). Asset life prediction multiple degradation indicators and failure events: a continuous space model approach. In: Eksploatacja i Niezawodnosc - Maintenance and Reliability; 11 (4): pp. 72-81. ISSN 1507-2711

[5] STASIAK-BETLEJEWSKA R. (2012). Value engineering as the way of quality problems solving in the steel construction management In: Manufacturing Technology, Vol. 12, No. 4, pp $242-247$

[6] IEC 60050-192:2014 International Electrotechnical Vocabulary - Part 192: Dependability

[7] IEC 60300-3-2:2004 Dependability management - Part 3-2: Application guide - Collection of dependability data from the field

[8] IEC 61703/Ed2: Mathematical expressions for reliability, availability, maintainability and maintenance support terms

[9] EN 15341 Maintenance - Maintenance Key Performance Indicators

[10] WESSA, P. (2013). Maximum-likelihood Weibull Distribution Fitting (v1.0.3) in Free Statistics Software (v1.1.23r7), Office for Research Development and Education, URL http://www.wessa.net/rwasp_fitdistrweibull.wasp/

[11] LEGÁT, V. a kol. (2013). Management a inženýrství údržby, Professional Publishing, Praha, ISBN 978-80-7431119-2

[12] ALEŠ, Z., PEXA, M., PETERKA, B., HOLEK, M. (2010). Compressor maintenance supported by tribodiagnostics. In: Manufacturing Technology, Vol. 10, No. 10, pp. 87-93. ISSN 1213-2489

[13] MAYER, K., PEXA, M., PAVLU゚, J. (2012). Impact of technical diagnostics interval on machinery maintenance. In: Manufacturing Technology, Vol. 12, No. 12, pp. 42-46. ISSN 1213-2489 